\title{
A study of post operative pleuropulmonary complications of abdominal surgeries attending in a tertiary care hospital at Kakinada
}

\author{
M. Kiran ${ }^{1, *}$, Sudha Prasuja Nakka ${ }^{3}$, Mohana Pradeepika ${ }^{4}$ \\ ${ }^{\mathbf{1}}$ Assistant Professor, ${ }^{2}$ Professor, ${ }^{\mathbf{3} 4}$ Post Graduate, Dept. of Pulmonary Medicine, Rangaraya Medical College, Kakinada, Andhra \\ Pradesh, India
}

*Corresponding Author:

Email: kirandr2014@gmail.com

\begin{abstract}
Introduction: Postoperative pulmonary complications (PPCs) following abdominal surgery are frequent and associated with increased morbidity and mortality and hospital length of stay. Incidence rates vary dramatically, ranging from $2 \%$ to $40 \%$. The incidence of pleuro-pulmonary complications shows wide variations \& has the diversity of various influencing factors, including patient existing lung conditions, habitual history, selection of surgery, anaesthetic risks and post-surgical recovery.

Material and Methods: 100 patients are selected from in \& out patient department \& causality in GGH, Kakinada attending for abdominal surgical conditions. It is a prospective- observational, cross sectional study.

Results: In the studied group of 100 person's total of 27 persons affected with pulmonary complications in overlapped manner. Following pulmonary complications observed with incidence rates respectively in the order of ATELECTASIS (74.07\%), PLEURAL EFFUSION (62.96\%), PNEUMONIA (62.96\%), RESPIRATORY FAILURE (11.11\%).

Conclusion: The incidence of postoperative pleuropulmonary complications of abdominal surgeries in our study in GGH, Kakinada is $27 \%$, which includes atelecasis as the predominant one $(74 \%)$ followed by pleural effusion and pneumonia each carrying equal incidence $(62.96 \%)$ and finally respiratory failure that occupied least. Early prediction of postoperative pulmonary complications is possible to have the early interventions to reduce the post op morbidity, hospital length of stay and cost.
\end{abstract}

Keywords: Atelectasis, Pleural effusion, Pneumonia, Respiratory failure.

\section{Introduction}

"Postoperative pulmonary complications (PPCs) following abdominal surgery are frequent and associated with increased morbidity and mortality and hospital length of stay. Most investigators include postoperative pneumonia (confirmed or suspected), respiratory failure (usually defined as the need for ventilator support) and bronchospasm, but analysis of the literature shows that other complications, such as unexplained fever, excessive bronchial secretions, productive cough, abnormal breath sounds, atelectasis or hypoxemia, may also be included. The incidence of PPC varies depending on the clinical treatment setting, the kind of surgery studied, and the definition of PPC used. Incidence rates vary dramatically, ranging from $2 \%$ to $40 \%$. The frequency of these complications has remained relatively constant due to the increased number and complexity of the operations performed and the increased acuity and age of patients[1].

The incidence of pleuro-pulmonary complications shows wide variations \& has the diversity of various influencing factors, including patient existing lung conditions, habitual history, selection of surgery, anaesthetic risks and post-surgical recovery[2]. This study identified risk indicators for pulmonary complications after elective abdominal operations." It is interesting to see higher complication rates through the years despite new surgical techniques." Higher complication rates through the years may be a result of more aggressive surgeries defined for various malignant diseases. Pneumonia, ARDS, and respiratory failure increased significantly over the time whereas atelectasis and pleural effusions decreased over time.

\section{Aims and Objectives}

1. To know the incidence of pleuro pulmonary complications of abdominal surgeries.

2. To know the association of risk factors to the postoperative pleuro pulmonary complications of abdominal surgeries.

\section{Materials and Methods}

100 patients are selected for the study, from in\& out patient departments \& causality in GGH, Kakinada attending for abdominal surgical conditions from august 2017 to august 2018.

Study design: it is a prospective- observational, cross sectional study.

Inclusion criteria: Patients included in the study are who selected for abdominal surgeries of age more than 18 years, fit for surgery, \& assessed to be having postoperative pulmonary complications based on productive cough ,pyrexia ,respiratory distress, physical chest signs ,radiological evidence. ABG analysis

Exclusion criteria: 1. Patients with severe comorbid conditions, emergency surgical conditions where there is no scope for history taking and respiratory system assessment, associated with severe morbidity 2 . Those who refused informed consent 3 . Age below 18 years 4 . Associated with cardiovascular risk factors.

Study Protocol: Hundred of such patients are selected for the study \& detailed clinical history pertaining to 
respiratory system, history regarding smoking, previous lung disease like asthma, COPD, pneumonia, pleural effusion is enquired. All the patients investigated with $\mathrm{x}$ ray chest, complete blood picture, spirometry, ABG analysis, sputum analysis, ultrasound chest, ECG and routine blood investigations and during the surgery duration of surgery \& anesthesia, complications if any, the type of abdominal incision noted. In the early postoperative period recovery time, shifting time from resuscitation ICU, need for mechanical ventilation, and presence of nasogastric tube are noted. Differences in the incidence rates of different complications are tested by chi square test for statistical significance.

\section{Results and Observations}

In the study group of hundred patients undergone for abdominal surgeries in GGH Kakinada the following pulmonary complications observed ATELECTASIS, PLEURAL EFFUSION, PNEUMONIA, RESPIRATORY FAILURE

Table 1: Percentage of complications in abdominal surgeries

\begin{tabular}{|c|c|c|}
\hline $\begin{array}{c}\text { Total } \\
\text { surgeries }\end{array}$ & $\begin{array}{c}\text { No of persons had } \\
\text { complications }\end{array}$ & \% \\
\hline 100 & 27 & 27 \\
\hline
\end{tabular}

Table 2: Incidence rates of different pulmonary complications observed in post-operative period of abdominal surgeries. (Study group consists of 100 patients)

\begin{tabular}{|l|c|c|c|}
\hline & $\begin{array}{c}\text { Total } \\
\text { no }\end{array}$ & $\begin{array}{c}\text { Complication } \\
\text { specific }\end{array}$ & \% \\
\hline Pleural effusion & 27 & 17 & 62.96 \\
\hline Pneumonia & 27 & 17 & 62.96 \\
\hline Atelectasis & 27 & 20 & 74.07 \\
\hline Respiratory failure & 27 & 03 & 11.11 \\
\hline
\end{tabular}

Table 3: Association of age with pulmonary complications of abdominal surgeries (p value $<0.05)$

\begin{tabular}{|c|c|c|c|}
\hline Age & $\begin{array}{c}\text { Total } \\
\text { No }\end{array}$ & Complications & \% \\
\hline$<50$ & 61 & 11 & 18.03 \\
\hline$>50$ & 39 & 16 & 41.02 \\
\hline
\end{tabular}

Table 4: Association of SEX with pulmonary complications

\begin{tabular}{|l|c|c|c|}
\hline \multicolumn{1}{|c|}{ Sex } & $\begin{array}{c}\text { Total } \\
\text { no }\end{array}$ & $\begin{array}{c}\text { No of persons with } \\
\text { complications }\end{array}$ & $\%$ \\
\hline Male & 33 & 15 & 45.45 \\
\hline Femaie & 67 & 12 & 17.91 \\
\hline
\end{tabular}

The above observation denotes that the male sex is more prone for pulmonary complications as they are associated with more risk factors like smoking and alcoholism and other comorbidities

Table 5: Association of type of abdominal incisions with post-operative pulmonary complications

\begin{tabular}{|l|c|c|c|}
\hline $\begin{array}{c}\text { Type of } \\
\text { incision }\end{array}$ & $\begin{array}{c}\text { Total } \\
\text { no }\end{array}$ & $\begin{array}{c}\text { No of persons with } \\
\text { complications }\end{array}$ & $\%$ \\
\hline High & 45 & 19 & 42.22 \\
\hline Low & 55 & 08 & 14.54 \\
\hline
\end{tabular}

Table 6: Association of smoking with post-operative pulmonary complication following abdominal surgeries

\begin{tabular}{|l|c|c|c|}
\hline \multicolumn{1}{|c|}{ Category } & $\begin{array}{c}\text { Total } \\
\text { no }\end{array}$ & $\begin{array}{c}\text { No of persons with } \\
\text { complications }\end{array}$ & \% \\
\hline Smokers & 41 & 18 & 43.90 \\
\hline Non smokers & 59 & 09 & 15.25 \\
\hline
\end{tabular}


Table 7: Association of pre-existing lung diseases with post-operative pulmonary complications following abdominal surgeries

\begin{tabular}{|l|c|c|c|}
\hline $\begin{array}{c}\text { Association with pre-existing } \\
\text { respiratory } \\
\text { diseases(BA,COPD) disease }\end{array}$ & $\begin{array}{c}\text { Total } \\
\text { no }\end{array}$ & No. & \% \\
\hline With & 37 & 17 & 45.94 \\
\hline Without & 63 & 10 & 15.87 \\
\hline
\end{tabular}

Table 8: Association duration of surgeries with the development of postoperative pulmonary complications

\begin{tabular}{|c|c|l|c|}
\hline $\begin{array}{c}\text { Duration of } \\
\text { surgery }\end{array}$ & $\begin{array}{c}\text { Total number } \\
\text { of persons }\end{array}$ & $\begin{array}{c}\text { Persons with } \\
\text { complications }\end{array}$ & $\%$ \\
\hline$<210$ minutes & 70 & 17 & 24.28 \\
\hline$>210$ minutes & 30 & 10 & 33.33 \\
\hline
\end{tabular}

Table 9: Showing different pulmonary complications and combinations of more than one complications and their percentages in total complications

\begin{tabular}{|l|l|c|c|}
\hline & \multicolumn{1}{|c|}{ Complications } & $\begin{array}{c}\text { No. of } \\
\text { persons }\end{array}$ & $\%$ \\
\hline 1 & Pleural effusion only & 01 & 3.07 \\
\hline 2 & Atelectasis only & 04 & 14.8 \\
\hline 3 & Pneumonia only & 02 & 07.4 \\
\hline 4 & Pleural effusion + pneumonia & 02 & 07.4 \\
\hline 5 & Pleural effusion + atelectasis & 04 & 14.8 \\
\hline 6 & Respiratory failure + atelectasis & 01 & 3.70 \\
\hline 7 & Respiratory failure + pneumonia & 02 & 07.4 \\
\hline 8 & $\begin{array}{l}\text { Pleural effusion + pneumonia }+ \\
\text { atelectasis }\end{array}$ & 10 & 37.0 \\
\hline 9 & Pneumonia + atelectasis & 01 & 3.7 \\
\hline & Total & 27 & \\
\hline
\end{tabular}

Table 10: Association sex with complications

\begin{tabular}{|l|c|c|c|c|c|}
\hline \multicolumn{1}{|c|}{ Sex } & $\begin{array}{c}\text { Total no. } \\
\text { of persons }\end{array}$ & $\begin{array}{c}\text { Pleural } \\
\text { effusion }\end{array}$ & Atelectasis & Pneumonia & $\begin{array}{c}\text { Respiratory } \\
\text { failure }\end{array}$ \\
\hline Males & 33 & $09(27.2 \%)$ & $12(36.36 \%)$ & $10(33.30 \%)$ & $02(13.33 \%)$ \\
\hline females & 67 & $08(11.9 \%)$ & $08(11.94 \%)$ & $07(10.44 \%)$ & $01(8.33 \%)$ \\
\hline
\end{tabular}

Table 11: Association of age with complications

\begin{tabular}{|c|c|c|c|c|c|}
\hline Age & $\begin{array}{c}\text { Total no. } \\
\text { of persons }\end{array}$ & $\begin{array}{c}\text { Pleural } \\
\text { effusion }\end{array}$ & atelectasis & pneumonia & $\begin{array}{c}\text { Respiratory } \\
\text { failure }\end{array}$ \\
\hline$<50$ & 61 & $06(9.83 \%)$ & $0711.47 \%)$ & $07(11.47 \%)$ & $00(00 \%)$ \\
\hline$>50$ & 39 & $11(28.20 \%)$ & $13(33.33 \%)$ & $10(25.64 \%)$ & $03(7.69 \%)$ \\
\hline
\end{tabular}

Table 12: Association of abdominal incision with complications

\begin{tabular}{|l|c|c|c|c|c|}
\hline $\begin{array}{c}\text { Type of } \\
\text { Incision }\end{array}$ & $\begin{array}{c}\text { Total no. } \\
\text { of persons }\end{array}$ & $\begin{array}{c}\text { Pleural } \\
\text { effusion }\end{array}$ & Atelectasis & Pneumonia & $\begin{array}{c}\text { Respiratory } \\
\text { failure }\end{array}$ \\
\hline High & 45 & $12(26.66 \%)$ & $14(31.11 \%)$ & $16(35.55 \%)$ & $03(6.66 \%)$ \\
\hline Low & 55 & $05(9.09 \%)$ & $06(10.90 \%)$ & $01(1.81 \%)$ & $00(00 \%)$ \\
\hline
\end{tabular}

Table 13: Association of smoking with complications

\begin{tabular}{|l|l|l|l|l|l|}
\hline & $\begin{array}{c}\text { Total no. } \\
\text { of persons }\end{array}$ & $\begin{array}{c}\text { Pleural } \\
\text { effusion }\end{array}$ & Atelectasis & Pneumonia & $\begin{array}{c}\text { Respiratory } \\
\text { failure }\end{array}$ \\
\hline Smokers & 41 & $12(29.26 \%)$ & $15(36.58 \%)$ & $12(29.26 \%)$ & $03(7.31 \%)$ \\
\hline $\begin{array}{l}\text { Non } \\
\text { smokers }\end{array}$ & 59 & $05(8.47 \%)$ & $05(8.47 \%)$ & $05(8.47 \%)$ & $00(00 \%)$ \\
\hline
\end{tabular}


Table 14: Association of lung disease with complications

\begin{tabular}{|l|c|c|c|c|c|}
\hline $\begin{array}{c}\text { Lung } \\
\text { diseases (BA, } \\
\text { COPD })\end{array}$ & $\begin{array}{c}\text { Total no. } \\
\text { of persons }\end{array}$ & $\begin{array}{c}\text { Pleural } \\
\text { effusion }\end{array}$ & Atelectasis & Pneumonia & $\begin{array}{c}\text { Respiratory } \\
\text { failure }\end{array}$ \\
\hline Yes & 37 & $12(32.43 \%)$ & $15(40.54 \%)$ & $12(32.43 \%)$ & $03(8.10 \%)$ \\
\hline No & 63 & $05(12.85 \%)$ & $05(7.93 \%)$ & $05(7.93 \%)$ & $00(00 \%)$ \\
\hline
\end{tabular}

Table 15: Association of duration surgery with complications

\begin{tabular}{|l|c|c|c|c|c|}
\hline Minutes & $\begin{array}{c}\text { Total no. } \\
\text { of persons }\end{array}$ & $\begin{array}{c}\text { Pleural } \\
\text { effusion }\end{array}$ & Atelectasis & Pneumonia & $\begin{array}{c}\text { Respiratory } \\
\text { failure }\end{array}$ \\
\hline$<210$ & 70 & $09(12.85 \%)$ & $12(17.14 \%)$ & $09(12.85 \%)$ & $01(3.33 \%)$ \\
\hline$>210$ & 30 & $08(26.66 \%)$ & $08(26.66 \%)$ & $08(26.66 \%)$ & $02(2.85 \%)$ \\
\hline
\end{tabular}

\section{Discussion}

Preoperative assessment[3] of patients scheduled to undergo upper abdominal surgery assists the physician in determining preoperative risk. Physiological changes that occur after laparotomy[8], including alterations in lung volume, ventilatory gas exchange and respiratory defense mechanisms, impose an increased risk of pulmonary complications[5] for susceptible patients . In this study we observed a PPC incidence of $27 \%$ (27/100). However, other studies have shown a wide variation, between 10 and $80 \%$ in the incidence of PPCs following abdominal surgery, because there is no standard definition of PPC"s and also interplay of multiple risk factors. In this study the relatively low incidence of pulmonary complications was due to the fact that patients was undergoing prophylactic measures to avoid such complications.

1. Atelectasis is the most frequent complication observed in our sudy $(74 \%=20 / 27)$. It was associated with pleural effusion and not occurred alone. More than one complication is frequently observed in the same patient at the same time. Only four of our patients affected with atelectasis alone and rest of others affected in combination with pleural effusion, pneumonia, respiratory failure. The association of pleural effusion with atelectasis showed $51.85 \%$ which signifies the strong interrelationship of both conitions. Most atelectasis occurs near diaphragm in supine posture and less towards the apex. with cardiopulmonary by pass atelectasis is more prominent than after other forms of surgery even thoracotomies. Increasing $\mathrm{FiO} 2$ at the end of surgery to 1.0 before extubation will favour atelectasis formation, persisting in postoperative period[5]. Using $80 \%$ oxygen compared with $30 \%$ reduces the incidence of postoperative nausea and vomiting from $30 \%$ to $17 \%$. More importantly use of $80 \%$ oxygen during colorectal resection halved the incidence of surgical wound infection compared with $\mathrm{FiO} 2$ of 0.3 . Most of the atelectasis appearing during general anaesthesia[4] resolves within 24hrs after surgery. A Vital Capacity Maneuver (VCM) can completely abolish atelectasis that develops after induction of general anaesthesia. an airway pressure of $30 \mathrm{~cm} \mathrm{H} 20$ reduces atelectasis, only with a pressure of $40 \mathrm{~cm} \mathrm{H} 2 \mathrm{O}$ maintained for 15 secs atelectatic lung tissue fully expand. this maneuver has been called the VCM. . Use of bilevel positive airway pressure (BiPAP) system to treat obese patients for the first $24 \mathrm{hrs}$ after upper abdominal surgery significantly reduced pulmonary dysfunction[13].

2. Pulmonary infection (pneumonia or tracheobronchitis) accounted for $62.96 \%$ percent (17/27) of the patients with PPCs. 11.11 percent of these patients (03/27) developed acute respiratory failure with prolonged intensive care treatment and hospitalization. Studies have found that 40 to $60 \%$ of ambulatory patients would be defined as "high risk" for aspiration pneumonitis, use of metoclopramide in combination with a $\mathrm{H}$ 2antagonist has been advocated to decrease postoperative emesis and further reduction in the risk of aspiration pneumonitis. Treatment should include intubation and ventilation if respiratory failure is severe. Broad spectrum coverage is prudent. Specific coverage with antibiotics is dictated by culture results [7]. The incidence of respiratory tract infection in patients requiring an endotracheal tube can be as high as 17 to $20 \% .78$, 79 Approximately $60 \%$ of nosocomial infections are caused by aerobic gram-negative bacterias and $20 \%$ are caused by viral infection (an important source of morbidity and mortality in immunocompromised patients ). Ventilators and breathing circuits are heavily contaminated with microorganisms from the patient's oropharynx and trachea. Therefore, disposable circuits or disinfection of components used in the breathing system is equally effective in preventing cross infection between patients. Pulmonary toilet and culture-specific antibiotic remain the basic treatment plan. Initially, coverage with broadspectrum antibiotics may be needed until microbiology results are known, but then a tailored antibiotic regimen is strongly recommended.

3. Pleural effusion also running parallel to the atelectasis with complication rate of $62.96 \%$. The Effusions are all disappeared spontaneously over 
the subsequent 3 to 12 days without any specific therapy, with the exception of the infected effusion in some patients.Perfusion lung scans done in some individuals with larger effusions (over $10 \mathrm{~mm}$ thick) did not demonstrate segmental filling defects suggestive of pulmonary embolism. There are many possible causes for postoperative pleural effusions. Hypervolemia during or after surgery leads to transudate effusion[9]. The pancreas may be manipulated during the surgery, leading to pancreatitis and a resultant pleural effusion; the amylase level in the pleural fluid should be elevated, and since in only two of the larger effusions was it elevated slightly, it appears that pancreatitis accounts for very few of the effusionsin the present series. the effusions associated with subphrenic abscess usually do not become manifest until about ten days after surgery. ${ }^{10}$ The significant $(\mathrm{P}<0.01)$ relationship between the presence of atelectasis and pleural fluid in our series suggests that one of these two mechanisms is operative. If increased negative pleural pressure is the explanation, a transudative pleural effusion should result. Conversely, if pneumonitis is the explanation, the pleural effusion should be an exudate[12]." Unfortunately, since most of the effusions were too small to examine, it is impossible to say which mechanisms predominate. the presence of free peritoneal fluid at the time of surgery appeared to be related to the postoperative development of pleural fluid. The present study shows that pleural effusions frequently occur in the first few days after abdominal surgery[13]. They are related in most instances to atelectasis, peritoneal fluid, or irritation of the diaphragm. Their development should not be regarded as a serious complication, as almost all resolve spontaneously. When effusions occur, a diagnostic thoracocentesis to rule out pleural infection should be performed. A low $\mathrm{pH}(<7.20)$ in the pleural fluid is a sensitive indicator that pleural infection is present. Some pleural effusions might be related to postoperative sodium and water retention, and aggravated by an age-related relative cardiac decompensation. Early postoperative pleural effusions are common and do not require specific treatment.

4. Respiratory failure is being occupying $3.7 \%$ in association with atelectasis and $7.4 \%$ in combination with pneumonia[14]. We found the smoking habbit, age $>50$, high abdominal incisions, associated lung diseases complicated the other complications with respiratory failure [15]. It has been suggested that respiratory muscle dysfunction may be responsible for a number of pulmonary complications. The side of the operation, as well as the type, are the most important factors affecting the respiratory muscles. the incidence of significant respiratory muscle dysfunction after lower abdominal surgery[16] is very low (2-5\%) while that of upper abdominal surgery may approach 20-40\%. Respiratory muscle dysfunction may play a significant role in the breathing pattern. The decrease in maximum inspiratory, transdiaphragmatic, and expiratory muscle pressures observed after upper abdominal surgery in several studies. This decrease is sustained for 48 hours after surgery and may persist for a week, gradually returning to normal. Although anaesthesia and pain may be responsible for dysfunction of the respiratory muscles, studies in animals and humans support the hypothesis that an inhibitory reflex generated during the surgical procedure is the major mechanism. This reflex inhibition of the phrenic nerve output has been postulated to be elicited by the manipulation of the gallbladder and other splanchnic organs.

The main factors traditionally associated with PPCs are chronic airways disease, advanced age, upper abdominal surgery, prolonged duration of surgery, history of smoking, and obesity[10]. To select the risk factors to be included in logistic regression for PPC we chose the variables based on $p$ value of the chi square test in a stepdown significance procedure. The variables were included in the following sequence: previous lung disease $(\mathrm{p}=0.0001)$, respiratory symptoms $(\mathrm{p}=$ $0.0001)$, comorbidity $(p=0.007)$, age over 50 years old $(\mathrm{p}=0.03)$, surgery duration over 210 minutes $(\mathrm{p}=$ $0.03)$, habitual smoking $(\mathrm{p}=0.04)$, current smoking ( $\mathrm{p}$ $=0.04)$ and obesity $(\mathrm{p}=0.10)[11]$. The logistic regression in our study showed the same risk factors as found in the literature. We found that the presence of chronic pulmonary disease is also strongly associated with PPCs, particularly if the patient's surgery lasted longer than 210 minutes and comorbidity was present. Old age beyond 50 years increase the incidence of pulmonary complications[17]. The possible explanation for this may be: (a) decrease in static lung volume, (b) diminished MEFR, (c) reduced pulmonary elastic recoil, (d) reduction in $\mathrm{PaO}$. Development of pulmonary complications seems to be more in males $\mathbf{( 5 5 . 5 5 \% )}$ than in females $\mathbf{( 4 4 . 4 5 \% )}$ possibly due to smoking habits[19] of men, more dependency of diaphragmatic breathing and bronchial "catarrah". Although obesity is a recognised risk factor, most of our patients belonged to the lower socioeconomic strata; hence no firm conclusion could be drawn. Only four patients in our group were obese and developed pleural effusion with atelectasis, two of them developed respiratory failure as an additional complication and wound dehiscence.

\section{Conclusion and Summary}

The incidence of postoperative pleuropulmonary complications of abdominal surgeries in our study in GGH, Kakinada is $27 \%$, which includes atelecasis as 
the predominant one (74\%) followed by pleural effusion and pneumonia each carrying equal incidence $(62.96 \%)$ and finally respiratory failure that occupied least. Early prediction of postoperative pulmonary complications is possible to have the early interventions to reduce the post op morbidity, hospital length of stay and cost[20].

\section{References}

1. Lee J, Larson R, Buckley J et al. Airway maintenance in morbidly obese. Anesth Rev 1980;7:33.

2. Warner DO. Preventing postoperative pulmonary complications: the role of anaesthesiologist. Anesthesiol 2000;92:1467-72.

3. Smetana GW. Preoperative pulmonary evaluation. $N$ Engl J Med 1999;340:937-44.

4. Pedersen T, Viby-Mogensen J, Ringsted C. Anaesthetic practice and postoperative pulmonary complications. Acta Anaesthesiol Scand 1992;36:812-18.

5. Arozullah AM, Conde MV, Lawrence VA. Preoperative evaluation for postoperative pulmonary complications. MedClin N Am 2003;87:153-73.

6. Arozullah A, Daley J, Henderson W et al. Multifactorial risk index for predicting postoperative respiratory failure in men after noncardiac surgery. Ann Surg 2000;232:24353.

7. Arozullah AM, Khuri SF, Henderson WG et al. Development and validation of a multifactorial risk index for predicting postoperative pneumonia after major noncardiac surgery. Ann Intern Med 2001;135:847-57.

8. Ondrula DP, Nelson RL, Prasad ML, Coyle BW, Abcarian H. Multifactorial index of preoperative risk factors in colon resections. Dis Colon Rectum 1992;35:117-22.

9. Gibbs JPC, Henderson W, Daley J, Hur Kwan MS, Khuri, Shukri F. Preoperative serum albumin level as a predictor of operative mortality and morbidity: results from National VA Surgical Risk Study. Arch Surg 1999;134:36-42.

10. Kroenke K, Lawrence VA, Theroux JF, Yuley MR. Operative risk in patients with severe obstructive pulmonary disease. Arch Intern Med 1992;152:967-71.

11. Moller AM, Mssloe R, Pedersen T. Postoperative intensive care admittance: the role of tobacco smoking. Acta Anesthesiol Scand 2001;45:345-48.
12. Thomas DR, Ritchie CS. Preoperative assessment of older adults. J Am Geriutr Soc 1995; 43: 811-21.

13. Brooks-Brunn JA. Predictors of postoperative pulmonary complications following abdominal surgery. Chest 1997;111:564-71.

14. Gupta H, Gupta PK, Fang X, Miller WJ, Cemaj S, Forse RA, Morrow LE. Development and validation of a risk calculator predicting postoperative respiratory failure. Chest 2011;140(5):1207-15. Epub 2011 Jul 14.

15. Svensson LG, Hess KR, Coselli JS, Safi HJ, Crawford ES. A prospective study of respiratory failure after highrisk surgery on thoracoabdominal aorta. J Vasc Surg 1991;14:271-82.

16. Ebert JP, Grimas B, Niemann KMW. Respiratory failure secondary to homologous blood transfusion. Anesthesiol 1985;63:104-6.

17. Development and Validation of a Multifactorial Risk Index for Predicting Postoperative Pneumonia after Major Noncardiac Surgery Ahsan M. Arozullah, MD, MPH; Shukri F. Khuri, MD; William G. Henderson, PhD; and Jennifer Daley, MD, for the Participants in the National Veterans Affairs Surgical Quality Improvement Program

18. Eagle KA, Berger PB, Calknis H. ACC/AHA guideline update for postoperative cardiovascular evaluation for noncardiac surgery: executive summery: a report of American College of cardiology, American Heart association Task Force on Practice Guidelines (Committee to update the 1996 Guidelines on Perioperative Cardiovascular Evaluation for Noncardiac Surgery). J Am Coll Cardiol 2002;39;542-53.

19. Warner MA, Divertie MB, Tinker JH. Preoperative cessation of smoking and pulmonary complications in coronary artery bypass patients. Anesthesiol 1984;60:38083.

20. Smetana GW. Evaluation of preoperative pulmonary risk (Up to date review) Up To Date 2003;10: N3. http:/ www.uptodate.com (accessed Jun 30,2005.

How to cite this article: Kiran M, Nakka S. P, Pradeepika M. A study of post-operative pleuropulmonary complications of abdominal surgeries attending in a tertiary care hospital at Kakinada. Indian $\mathrm{J}$ Immunol Respir Med. 2018;3(4):217-222. 